\title{
Influence of System Quality, Information Quality, Service Quality on User Acceptance and Satisfaction and Its Impact on Net Benefits (Study of Information System Users Lecturer Performance Load (BKD) in Malang State University)
}

\author{
Rini, WIDIASTUTI, \\ Graduate Program of Higher Education Management, Faculty of Administrative Studies, \\ Brawijaya University, Malang, East Java, Indonesia \\ rini.widi@um.ac.id \\ Bambang Santoso, HARYONO, \\ Department of Public Administrative Science, Faculty of Administrative Science, \\ Brawijaya University, Malang, East Java, Indonesia \\ bambangsfia@ub.ac.id \\ Abdullah, SAID, \\ Department of Public Administrative Science, Faculty of Administrative Science, \\ Brawijaya University, Malang, East Java, Indonesia \\ abdullahsaid83@yahoo.co.id
}

\begin{abstract}
This study aims to examine the influence of system quality, information quality, and service quality of the lecturer at Malang State University. This study will also investigate the effect on user satisfaction and its impact on net benefits for users of UM Information System Expenses. This study applies a modification of the information system success model from DeLone \& McLean. The model is analyzed by modeling the Structural Equation Modeling (SEM) based on components or variants (component based) that are popular with Partial Least Square (PLS) using SmartPLS version 3.2.8. The results of this study are expected to be adopted as input and consideration in developing, improving, and improving the performance of the UM BKD information system. The research design used in this study is quantitative research. Respondents in this study were 93 UM PNS lecturers who were actively teaching. The questionnaire was online distributed by accessing the page provided. The results showed that there was a positive but not significant effect between system quality, information quality, and service quality on the use of the BKD system. However, there is a positive and significant influence between system quality, information quality, and service quality on the $B K D$ system user satisfaction, between the uses of the BKD system on net benefits, and between the satisfaction of the BKD system users on net benefits. The implementation of BKD UM information system can be declared successful because there is a positive correlation between variables.
\end{abstract}

Keywords: DeLone McLean Model, Information System, System Quality, Lecturer Performance Load, PLS-SEM

JEL Classification: D8, D82, H1, H11. 


\section{Introduction}

Higher education is an institution that organizes education has a significant role in the framework of national development, where the essential assets possessed by a college are human resources (HR).

According to Indonesia (2012) regarding Higher Education, in Article 4 point $b$, that Higher Education functions to develop academicians who are innovative, responsive, creative, skilled, competitive, and cooperative through the implementation of tri dharma. Tridharma is an obligation of universities to organize education, research and community service. Academic Society is an academic community consisting of lecturers and students.

Lecturers as state servants in each semester need to collect Lecturer Performance Load, hence called as BKD and Lecturer Performance Evaluation, hence called as EKD. BKD is collected for all lecturers as the responsibility of lecturers, in this case to the State University of Malang (UM), while EKD is collected for lecturers who have been certified as the responsibility of lecturers for their performance to the Directorate of Higher Education (Dirjendikti, 2010).

In conducting tri dharma activities, a lecturer is required to carry out educational and research activities of at least nine credits and duty of service to the community and supporting tasks of at least three credits. The indicator of the evaluation of lecturers' performance is the number of BKD evaluations carried out by each faculty in one year. All faculties carry out BKD evaluations so that the number of evaluations conducted in 2014 is 14 times or according to the target $(100 \%)$. Evaluation of the implementation of education and learning activities is carried out by the Quality Assurance Unit (SPM) based on the results of evaluations conducted by the Quality Assurance Unit at the faculty level and the results of evaluations conducted by the Quality Assurance Group (GPM) at the department level. This evaluation is carried out at the end of each semester (UM, 2015).

Based on [4] in the bureaucratic reform of the State University of Malang 2017 - 2019, it was explained that in the work program in the field of governance there was an expansion of the implementation of integrated e-government in governance and development by implementing a development action plan or new e-government system support the implementation of Ministry activities including database of lecturer performance.

Al. et al. (2016):58 state that Since the late 1990s, information technology and communications (ITC) have had a significant influence on society. This has come about primarily because of the development of the internet. Governments 
worldwide are beginning to recognize the opportunities ITC offers to meet user demands, and they have started to introduce information and transactions online in what is now known as e-government.

Information systems are a set of interconnected components that function to collect, process, store, and distribute information to support decision making and supervision in the organization. The information system design process is expected to function effectively. This effectiveness also indicates that the development of the information system is a success. Measurement of the success or effectiveness of information systems is essential for understanding the value of information system management activities and information system investments. (DeLone \& McLean, 1992) propose a model called D \& M IS Success Model as a framework for conceptualizing and operating the success of information systems.

Conducted a study at the University of Rome, Italy, which aimed to test the e-learning system based on student perceptions using the Information System Success Model (IS Success Model) (Efiloğlu, 2018). There are five variables in this study, namely system quality, information quality, system usage, user satisfaction, and system success. The analysis of this study used Partial Least Squares (PLS), Structural Equation Modeling (SEM). The findings on e-learning evaluation of this study indicate that system quality has a significant impact on system use and user satisfaction, the quality of information has a significant impact only on user satisfaction. Besides, the authors also found that user satisfaction and system usage had a positive and significant impact on the success of the system.

The development and implementation of Information and Communication Technology -based Management Information Systems is becoming increasingly important. ICT-based SIMs that have been successfully developed by UM include Academic Information Systems (SIAKAD), Student Information Systems, Staffing Information Systems (SIMPEGA), Information Systems Lecturer Performance Load (BKD), Public Information Systems, Financial Information Systems, and Integrated Library Information Systems (SIPADU).

The BKD in UM Information System was developed to meet the administrative requirements of workload and lecturer performance evaluation in the implementation of the Tridharma of Higher Education. BKD Information System can be accessed by users (in this case lecturers) online. Access rights of the BKD information system for lecturer users are to record or administer workloads and evaluate their performance in the database.

This study aims to examine the effect of system quality, information quality, and service quality on usage, in this case, UM lecturers. This study will also 
examine the effect on user satisfaction and the impact on net benefits on users of Information Systems Expense Lecturer Performance (BKD), State University of Malang (UM). This study uses a modification of the information system success model from DeLone \& McLean (2003).

\section{Theoretical Review}

Information systems are developed for different purposes, depending on the needs of human users and businesses. The development of a management information system is a shared responsibility between users and developers of information systems. Thus the user must be involved in the process of developing this management information system, especially in the stage of determining the needs and desires of the user. Then there are three forms of human involvement in the development of SIM which are low involvement, moderate involvement, and high involvement (Darmawan, 2013).

Lecturer Performance load Information System that has been developed at Malang State University make it accessible for UM lecturer users to administer workloads and evaluate their performance in implementing the main tasks of the Tridharma of Higher Education. Monitoring and evaluation in the Information Technology (IT) governance system is an IT performance assessment managed in the IT governance system. A good system is a system that can produce performance and benefits for its users. The frequently asked question is how to measure the success of information systems [11].

Many research has been done to identify the factors that led to the success of information technology systems. One well-known study in this area is research conducted by [(DeLone and McLean, 1992), who developed a parsimony model, a complete but simple model, called the DeLone and McLean information system success model (D \& M IS Success Model) in Figure 1. 
Figure 1. Information System Success Model DeLone \& McLean, 1992 (D \& M IS Success Model)

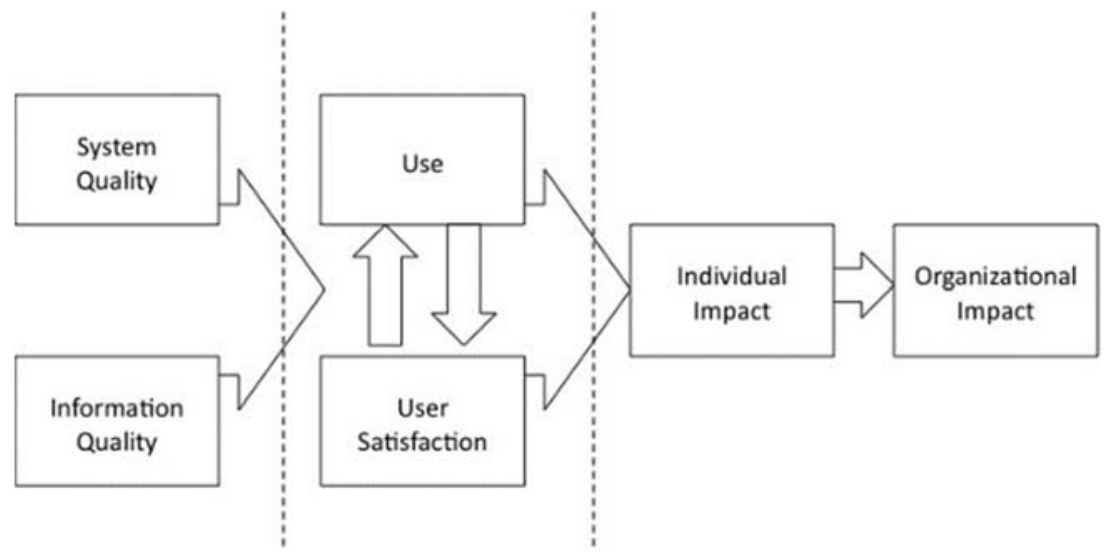

Based on the criticisms received and also based on developments in information technology systems and the environment of their use, (Delone \& Mclean, 2003), renewing the model by expanding it. Some are added from the old model in Figure 2.

Figure 2. The updated D \& M Information System Success Model (Delone \& Mclean, 2003): 24

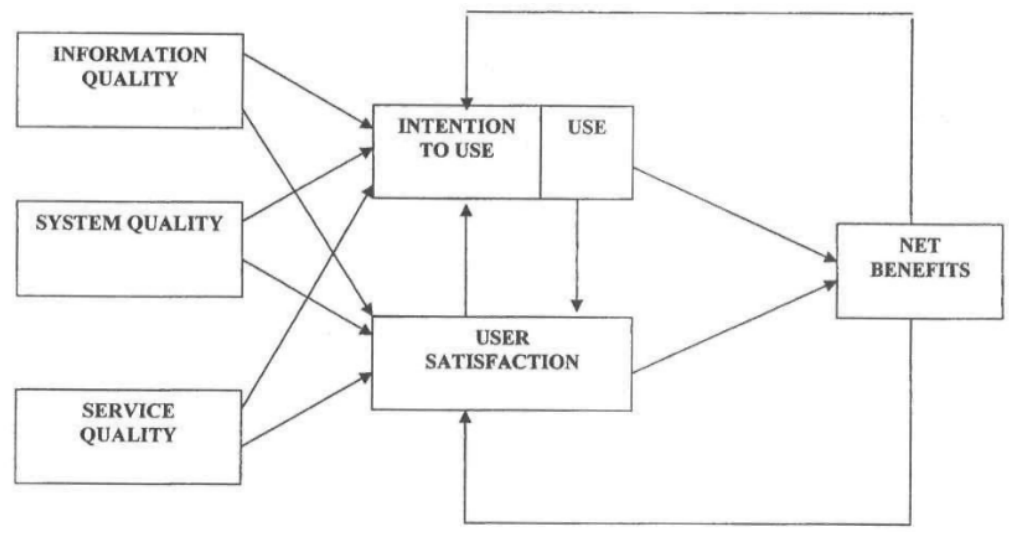

This model is considered suitable and can be used because the DeLone and McLean model has also been widely used by researchers to measure system success, such as previous studies (Delone \& Mclean, 2003), (Gorla et al., 2010), (Saha et al., 2012), (Efiloğlu, 2018), (Wu, 2007), (Radityo \& Zulaikha, 2007), (Supriyono, 2017), (Sharma \& Lijuan, 2015), (Nugroho et al., 2012), (Rana et 
al.,2014), (Almaiah \& Alismaiel, 2018), (Li, 1997), (Livari, 2005), and (Jogiyanto, 2007) where the model is the basis of the initial hypothesis of the study to be a reference in developing questionnaires to measure the successful implementation of the UM BKD information system.

In this study, the research instrument used to measure the quality of Information Systems UM Lecturer Performance Load refers to the latest DeLone and McLean model The Update D \& M IS Success Model. These dimensions include system quality, information quality, service quality, usage, user satisfaction, and net benefits.

\subsection{Quality System}

System quality is a phenomenon of system diversity. The variety of the system is used to measure the quality of its information technology system. The quality of the system in this study is the Lecturer Performance Load Information System (BKD) online, so it is a website-based information system. Wu (2007) states that system quality reflects interactions between websites and users. The relationship between system quality and website features is described in the table 1.

Table 1. The relationship between Website Quality and Feature Systems

\begin{tabular}{|l|l|l|}
\hline Category & \multicolumn{1}{|c|}{$\begin{array}{c}\text { Website Features that impact User } \\
\text { Satisfaction }\end{array}$} & \multicolumn{1}{c|}{ Study } \\
\hline \multirow{5}{*}{} & Speed & Abbott et al. 2000 \\
\cline { 2 - 3 } & Usefulness & Achrol \& Kotler 1999 \\
\cline { 2 - 3 } & Interactivity & Auger 2005 \\
\cline { 2 - 3 } System & Web performance & Chiou \& Shen 2006 \\
\cline { 2 - 3 } & Ease of use, purchase process & Cho \& Park 2001 \\
\cline { 2 - 3 } & Page loading speed, navigation efficiency & Gehrke \& Turban 1999 \\
\cline { 2 - 3 } & Navigation, search options, structure & Iwaarden et al. 2002 \\
\cline { 2 - 3 } & Accuracy of transaction, ease of use & Keeney 1999 \\
\cline { 2 - 3 } & Speed of transmission, convenience of use & Torkzadeh \& Dhillon 2002 \\
\cline { 2 - 3 } & Download time & Zhang \& Dran 2001 \\
\cline { 2 - 3 } & E-Commerce System Quality & Kim \& Lim 2001 \\
\cline { 2 - 3 } & Tangibles & Liu \& Arnett 2000 \\
\cline { 2 - 3 } & User interface quality & Molla \& licker 2001 \\
\cline { 2 - 3 } & Dynamic content & Parasuraman et al 1990 \\
\cline { 2 - 3 } & Versionability & Park et al. 2006 \\
\cline { 2 - 3 } & Download time & Parsons et al. 1998 \\
\cline { 2 - 3 } & System responsiveness, response time & Reisenwitz \& Cutler 1998 \\
\cline { 2 - 3 } & Internet ecology, Internet product choice & Spiller \& Lohse 1998 \\
& online payment & Tiwana 1998 \\
\cline { 2 - 3 } & Navigation, site technical features & \\
\hline
\end{tabular}

Source: Wu (2007): 11 


\subsection{Information Quality}

Romney \& Steinbart (2014) states that information is data that has been managed and processed to provide meaning and improve the decision-making process that is better than the requirements and quality of improving information. Measurement of information quality according to Marakas \& O'Brien (2017) consists of three dimensions, namely time, content, and form. Information quality measures the quality of output from information systems. Saha et al. (2012) summarize the construct of information quality in the table 2 .

\section{Table 2. Information Quality Measurement}

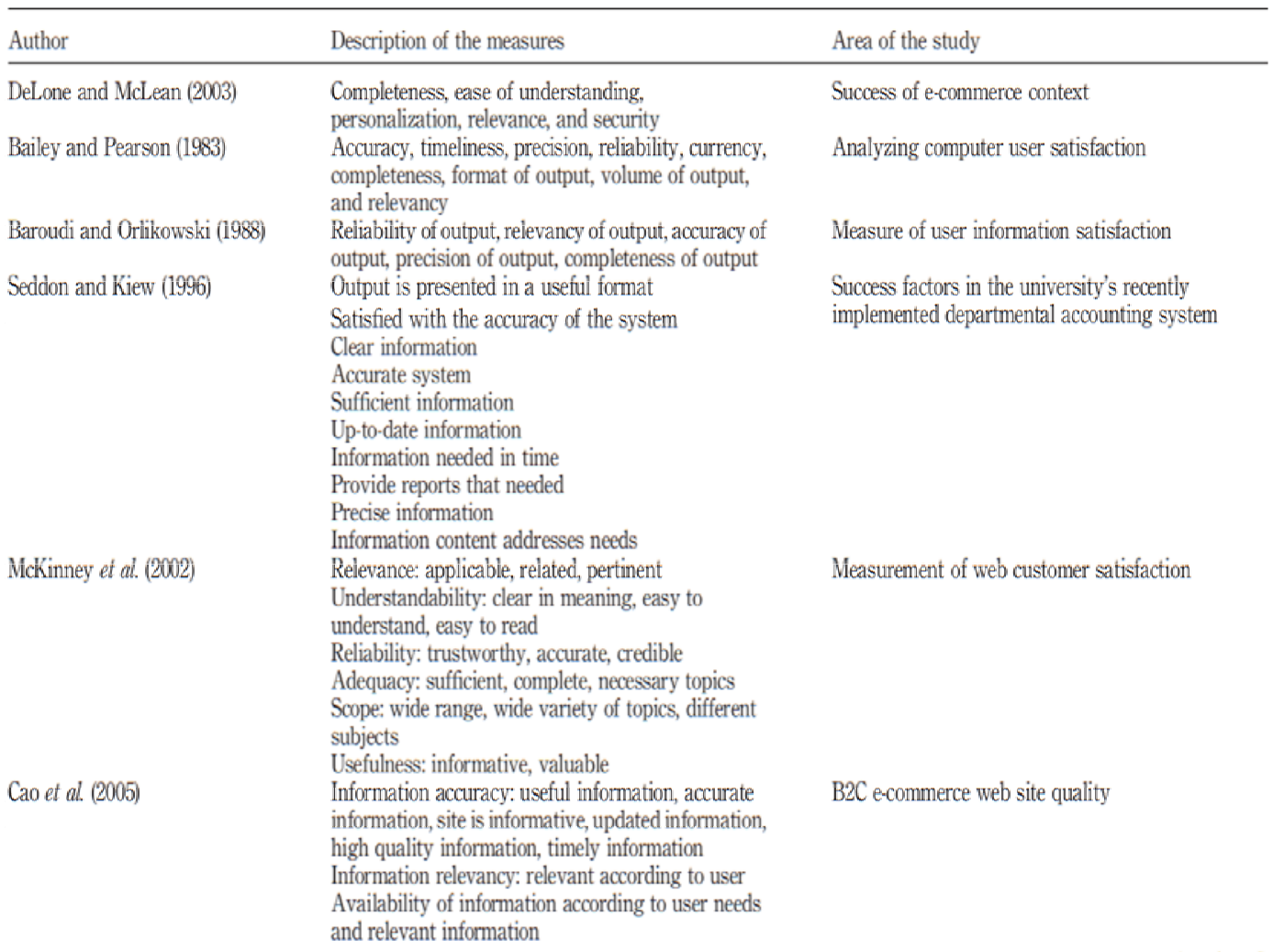


HOLISTICA Vol 10, Issue 3, 2019

\begin{tabular}{|c|c|c|}
\hline Li (1997) & $\begin{array}{l}\text { Accuracy of output, timeliness of output, precision of } \\
\text { output, reliability of output, currency of output, } \\
\text { completeness of output, and format of output }\end{array}$ & IS success factors \\
\hline Wangpipatwong et at. $(2005)$ & $\begin{array}{l}\text { Accuracy, timeliness, relevancy, precision, and } \\
\text { completeness }\end{array}$ & $\begin{array}{l}\text { Factors infuencing the adoption of e-government } \\
\text { web sites }\end{array}$ \\
\hline Roca et at. $(2006)$ & $\begin{array}{l}\text { System provides relevant information } \\
\text { System does not provide easy-to-understand } \\
\text { information } \\
\text { Output information is not clear } \\
\text { Information presentation in an appropriate format } \\
\text { Information content is very good } \\
\text { Information is up-to-date } \\
\text { Completeness of output information } \\
\text { Information delivered is not sufficient for purposes } \\
\text { Reliability of output information is high } \\
\text { Provides information in time }\end{array}$ & Acceptance of e-learning \\
\hline Rai ex al $(2002)$ & $\begin{array}{l}\text { Precise information according to user need } \\
\text { Provides output that is exactly what the user needs } \\
\text { Sufficient information to enable users to do tasks } \\
\text { Errors in the program that users must work around } \\
\text { Satisfied with the accuracy } \\
\text { Output options (print types, page sizes allowed for, } \\
\text { etc.) sufficient for user applications } \\
\text { Information provided was helpful regarding user } \\
\text { questions or problems }\end{array}$ & Success factors in integrated SIS at university \\
\hline Roldàn and Leai (2003) & $\begin{array}{l}\text { Current and timely information } \\
\text { Relevant, useful and significant information } \\
\text { Concise and summarized information } \\
\text { Accurate information } \\
\text { Orderly and clear information } \\
\text { Reasonable and logical information }\end{array}$ & Success factors in the Spanish EIS \\
\hline
\end{tabular}

Source: Saha et al. (2012): 308 - 309

\subsection{Service Quality}

The concept of service quality is primarily determined by how much the gap (gap) between the user's perception of the reality of the service received compared to the expectations of users of services that must be accepted. Service quality is generally measured by quick responsiveness, assurance, empathy, and following-up service. Service quality is also regulated by the effectiveness of online support capabilities such as answers to frequently asked questions, self-adaptable sites, and order tracking (Jogiyanto, 2007).

\subsection{Application}

The concept of using a system can be seen from several perspectives, namely actual use, and perceived use (application) reported. Usage refers to how often users use information systems. Concerning this matter, it is important to distinguish whether its use is a necessity that cannot be avoided or voluntary. The indicator measures this variable used only consists of one item, namely how often users (users) use the information system (Supriyono, 2017). 


\subsection{User Satisfaction}

User satisfaction is the user's response to the use of information system output. Some studies have found that user satisfaction is closely related to the attitude of the user to the use of information systems. The position of users towards information systems is a subjective criterion of how users like the system used. Indicators measure this variable according to (Delone \& Mclean, 2003), namely efficiency, effectiveness, and satisfaction.

\subsection{Net Benefits}

The impact of information systems has increased not only the effect on individual users and organizations but the effect on user groups, between organizations, consumers, social and even countries. Because of the many types of impacts, (Delone \& Mclean, 2003), proposes to name all benefits as a single benefit called net benefits. Net benefits are the impact of the existence and use of information systems on the quality of performance of users both individually and in organizations, including productivity, increasing knowledge and reducing the length of time information is sought (Jogiyanto, 2007).

\subsection{Structural Equation Modeling (SEM)}

SEM is a statistical technique that can analyze the pattern of the relationship between latent extracts and indicators, latent extracts from one another, and direct measurement errors. SEM is the development of the General Linear Model (GLM), a linear statistical model used in various analytical techniques (ANOVA, ANCOVA, MANOVA, MANCOVA, OLS, t-test, F-test), with multiple regression as the central part. But SEM is more reliable, illustrative, and more robust than regression techniques when modeling interactions, non-linearity, measurement errors, correlation error terms and correlations between latent variables (Urbach \& Müller, 2012).

\subsection{Partial Least Square (PLS)}

PLS is a variant-based structural equation (SEM) analysis that can simultaneously test measurement models while testing structural models. The measurement model is used to check validity and reliability, while the structural 
model is used to prove causality (testing hypotheses with prediction models). The fundamental difference between PLS which is a variant-based SEM with LISREL or AMOS based on covariance is the purpose of its use. Covariance-based SEM aims to estimate models for theory testing or confirmation, while SEM variants aim to predict models for theory development. Therefore PLS is a causality prediction tool used for theory development. In this study, analysis of research data will be carried out using PLS (SmartPLS version 3.2.8).

\section{Research Method}

The research design used in this study is quantitative research with the sample were 867 (civil servants) lecturers as users of the UM BKD Information System which spread to 8 faculties. The sample selection method is a purposive sampling method. Respondents in this study were 93 UM (civil servants) lecturers who were actively teaching.

\subsection{Hypothesis}

Based on (Delone \& Mclean, 2003), the hypothesis of this study is as follows $\mathrm{H} 1$ : There is an effect of system quality on the use of the BKD system

$\mathrm{H} 2$ : There is an influence of system quality on user satisfaction on the BKD system

$\mathrm{H} 3$ : There is an effect of information quality (information quality) on the use (use) of the BKD system

$\mathrm{H} 4$ : There is the influence of information quality (information quality) on user satisfaction of the BKD system

H5 : There is an effect of service quality on the use of the BKD system

$\mathrm{H} 6$ : There is the influence of service quality on user satisfaction of the BKD system

Then if system quality, information quality and service quality has been obtained; then it will be followed by a hypothesis that will find out whether there is a relationship between use, user satisfaction, and net benefits.

$\mathrm{H} 7$ : There is an influence of use (use) on user satisfaction of the BKD system H8 : There is the effect of using the net benefits of the BKD system.

H9 : There is an effect of user satisfaction on the net benefits of the BKD system 


\section{Results and Discussions}

The variables in this study consist of exogenous variables and endogenous variables. Exogenous variables in this study are:

1. Quality system

The indicators used to replicate from the study (Livari, 2005) consist of 6 measurement scales namely system flexibility, system integration, time to response, error recovery, the convenience of access, and language. This research also uses indicators based on research (Urbach \& Müller, 2012), namely ease of use and reliability and indicators based on research (Saha et al., 2012), namely the documentation of system, security of data, and navigation. System quality is defined as the assessment of users (lecturers and stakeholders) on the performance of the UM BKD information system.

2. Quality of information

Information quality measures the quality of output from information systems (Jogiyanto, 2007), Livari (2005) uses six measurement scales as follows: completeness, precision, reliability, currency, and format of the output. This research also uses indicators based on research (Delone \& Mclean, 2003), namely relevance, accurate, and timeless and indicators based on research (Marakas \& O'Brien, 2017), namely details and orders. Information quality is defined as the output size of the system, how to measure the quality of information produced by the UM BKD information system.

3. Service quality

Service quality as a comparison of customer expectations with perceptions of the real services they receive. (Delone $\&$ Mclean, 2003) three components affect the quality of service, namely assurance, empathy system, and system responsiveness. This research also uses indicators based on research (Saha et al., 2012), namely User's understanding of the systems. Service quality is a comparison of user expectations with perceptions of the real services they receive from the BKD system.

4. Application

According to (Jogiyanto, 2007), use differentiation is made into information use and system use. In the context of using the BKD UM information system, the intended use is the use of the BKD application or information system itself 
(system use). Replicating items used in research (Livari, 2005) were daily access time and frequency of usage.

5. User satisfaction

The attitude of users towards information systems is a subjective criterion of how users like the system used. Based on (Delone \& Mclean, 2003), this study uses five indicators, namely repeat purchase, repeat visit, efficiency, effectiveness, and satisfaction.

Endogenous variables in this study are:

1. Application

Replicating items used in the study (Livari, 2005) were daily access time and frequency of usage, which means the frequency of use is the frequency of system usage during work. System users are user behavior in interacting with the system and simultaneously using the output of the UM BKD system.

2. User satisfaction

System user satisfaction is the response and feedback that the user raises after using the information system. Based on (Delone \& Mclean, 2003), this study uses five indicators, namely repeat purchase), repeat visits, efficiency, effectiveness, and satisfaction. User satisfaction as a response or opinion of the system user to the interaction with the system and the use of output from the UM BKD system.

3. Net results obtained

Net benefits are net results or benefits perceived by individuals and organizations after implementing information systems. This study uses items adapted from the perceived usefulness measure in (Davis, 1989), namely: speed of publication task, job performance, effectiveness, and ease of job. This research also uses indicators based on research (Delone \& Mclean, 2003), namely job performance, task productivity, effectiveness, ease of job, usefulness, cost reduction, and decision making.

\subsection{Validity Test}

Testing the validity of the instrument using the Pearson Product Moment correlation analysis. Tests were carried out with a significance level of 0.05 (5\%) with the help of SPSS software. Based on Table $R$ if the correlation value is greater than 0.207 , then it is declared valid and vice versa as shown in the table 3 . 
Table 3. Test of Validity of Research Instruments

\begin{tabular}{|c|c|c|c|}
\hline Variable & Indicator & Correlation Coefficient & Conclusion \\
\hline \multirow{14}{*}{$\begin{array}{c}\text { System } \\
\text { Quality (SQ) }\end{array}$} & SQ1.1 & 0,672 & valid \\
\hline & SQ2.1 & 0,577 & valid \\
\hline & SQ3.1 & 0,766 & valid \\
\hline & SQ3.2 & 0,729 & valid \\
\hline & SQ4.1 & 0,728 & valid \\
\hline & SQ5.1 & 0,825 & valid \\
\hline & SQ6.1 & 0,753 & valid \\
\hline & SQ7.1 & 0,719 & valid \\
\hline & SQ8.1 & 0,827 & valid \\
\hline & SQ9.1 & 0,650 & valid \\
\hline & SQ9.2 & 0,794 & valid \\
\hline & SQ10.1 & 0,688 & valid \\
\hline & SQ11.1 & 0,757 & valid \\
\hline & SQ11.2 & 0,707 & valid \\
\hline \multirow{10}{*}{$\begin{array}{l}\text { Information } \\
\text { Quality (IQ) }\end{array}$} & IQ1.1 & 0,823 & valid \\
\hline & IQ2.1 & 0,738 & valid \\
\hline & IQ3.1 & 0,853 & valid \\
\hline & IQ4.1 & 0,866 & valid \\
\hline & IQ5.1 & 0,689 & valid \\
\hline & IQ6.1 & 0,674 & valid \\
\hline & IQ7.1 & 0,788 & valid \\
\hline & IQ8.1 & 0,821 & valid \\
\hline & IQ9.1 & 0,762 & valid \\
\hline & IQ10.1 & 0,788 & valid \\
\hline \multirow{7}{*}{$\begin{array}{l}\text { Service } \\
\text { Quality } \\
\text { (SEQ) }\end{array}$} & SEQ1.1 & 0,668 & valid \\
\hline & SEQ1.2 & 0,745 & valid \\
\hline & SEQ1.3 & 0,851 & valid \\
\hline & SEQ2.1 & 0,805 & valid \\
\hline & SEQ2.2 & 0,807 & valid \\
\hline & SEQ2.3 & 0,827 & valid \\
\hline & SEQ3.1 & 0,694 & valid \\
\hline \multirow[t]{2}{*}{ Use (USE) } & USE1.1 & 0,964 & valid \\
\hline & USE2.1 & 0,950 & valid \\
\hline \multirow{5}{*}{$\begin{array}{c}\text { User } \\
\text { Satisfaction } \\
\text { (US) }\end{array}$} & US1.1 & 0,830 & valid \\
\hline & US2.1 & 0,912 & valid \\
\hline & US3.1 & 0,910 & valid \\
\hline & US4.1 & 0,927 & valid \\
\hline & US5.1 & 0,864 & valid \\
\hline \multirow{3}{*}{$\begin{array}{l}\text { Net Benefits } \\
\text { (NB) }\end{array}$} & NB1.1 & 0,832 & valid \\
\hline & NB2.1 & 0,848 & valid \\
\hline & NB3.1 & 0,882 & valid \\
\hline
\end{tabular}




\begin{tabular}{|l|l|l|l|}
\hline \multirow{4}{*}{} & NB4.1 & 0,896 & valid \\
\cline { 2 - 4 } & NB5.1 & 0,807 & valid \\
\cline { 2 - 4 } & NB6.1 & 0,722 & valid \\
\cline { 2 - 4 } & NB7.1 & 0,737 & valid \\
\cline { 2 - 4 } & NB8.1 & 0,792 & valid \\
\hline
\end{tabular}

\subsection{Reliability Test}

The value of the reliability coefficient ranges from 0 to 1 . If the coefficient value is close to 1 , then the instrument is reliable. The measure used to show the statement is reliable if the Cronbach alpha value is above 0.6 . The reliability test results are summarized in the table 4.

Table 4. Test of Reliability of Research Instruments

\begin{tabular}{|c|c|c|}
\hline Variable & Alpha Cronbach & Conclusion \\
\hline SQ & 0,928 & reliabel \\
\hline IQ & 0,928 & reliabel \\
\hline SEQ & 0,885 & reliabel \\
\hline USE & 0,897 & reliabel \\
\hline US & 0,932 & reliabel \\
\hline NB & 0,927 & reliabel \\
\hline
\end{tabular}

\subsection{Measurement Model / Outher Model Test}

In this study, both validity and reliability testing were carried out using PLS analysis tools (SmartPLS version 3.2.8). PLS is an SEM technique that can analyze latent variables, indicator variables, and measurement errors directly.

\section{Convergent Validity}

The validity of convergence relates to the principle that the measurements of a construct should have a high correlation. Convergence validity test measured in PLS was assessed based on the loading factor indicator for each construct. Each indicator must have an external loading of more than 0.7. Based on these criteria, indicators whose loading values are less than 0.70 are dropped from the analysis. The table 5 shows the results of the external loading of each indicator to see the level of validity of the indicator. 
Table 5. Outer Loading (Mean, STDEV, T-Values)

\begin{tabular}{|c|c|c|c|c|c|}
\hline & Original Sample $(O)$ & Sample Mean (M) & Standard Deviation (STDEV) & T Statistics (|O/STDEV|) & P Values \\
\hline iq $1.1<-I Q$ & 0.832 & 0.831 & 0.037 & 22.771 & 0.000 \\
\hline iq10.1<- IQ & 0.801 & 0.803 & 0.044 & 18.060 & 0.000 \\
\hline iq $2.1<-1 Q$ & 0.744 & 0.745 & 0.048 & 15.360 & 0.000 \\
\hline iq3.1<- IQ & 0.852 & 0.852 & 0.034 & 25.423 & 0.000 \\
\hline iq4.1<- IQ & 0.865 & 0.866 & 0.026 & 33.863 & 0.000 \\
\hline iq7.1<- IQ & 0.785 & 0.786 & 0.036 & 21.554 & 0.000 \\
\hline iq8.1<- IQ & 0.839 & 0.840 & 0.033 & 25.800 & 0.000 \\
\hline iq9.1<- IQ & 0.790 & 0.790 & 0.045 & 17.617 & 0.000 \\
\hline $\mathrm{nb} 1.1<-\mathrm{NB}$ & 0.845 & 0.847 & 0.035 & 24.315 & 0.000 \\
\hline $\mathrm{nb} 2.1<-\mathrm{NB}$ & 0.861 & 0.859 & 0.037 & 23.185 & 0.000 \\
\hline $\mathrm{nb} 3.1<-\mathrm{NB}$ & 0.892 & 0.893 & 0.027 & 33.155 & 0.000 \\
\hline $\mathrm{nb} 4.1<-\mathrm{NB}$ & 0.903 & 0.905 & 0.022 & 40.718 & 0.000 \\
\hline $\mathrm{nb} 5.1<-\mathrm{NB}$ & 0.817 & 0.818 & 0.044 & 18.549 & 0.000 \\
\hline $\mathrm{nb} 6.1<-\mathrm{NB}$ & 0.706 & 0.708 & 0.066 & 10.626 & 0.000 \\
\hline $\mathrm{nb} 7.1<-\mathrm{NB}$ & 0.711 & 0.711 & 0.063 & 11.274 & 0.000 \\
\hline $\mathrm{nb} 8.1<-\mathrm{NB}$ & 0.773 & 0.772 & 0.046 & 16.674 & 0.000 \\
\hline seq1.2<- SEQ & 0.771 & 0.776 & 0.041 & 18.887 & 0.000 \\
\hline seq1.3<- SEQ & 0.862 & 0.863 & 0.033 & 26.347 & 0.000 \\
\hline seq2.1<- SEQ & 0.818 & 0.815 & 0.048 & 17.107 & 0.000 \\
\hline $\operatorname{seq} 2.2<-$ SEQ & 0.830 & 0.829 & 0.044 & 19.066 & 0.000 \\
\hline seq2.3<- SEQ & 0.806 & 0.801 & 0.058 & 13.827 & 0.000 \\
\hline sq11.1 <- SQ & 0.767 & 0.770 & 0.037 & 20.714 & 0.000 \\
\hline sq11.2 <- SQ & 0.754 & 0.750 & 0.054 & 13.899 & 0.000 \\
\hline sq3.1<- SQ & 0.759 & 0.754 & 0.053 & 14.320 & 0.000 \\
\hline $\mathrm{sq} 3.2<-\mathrm{SQ}$ & 0.720 & 0.717 & 0.060 & 11.895 & 0.000 \\
\hline sq4.1<- SQ & 0.730 & 0.720 & 0.066 & 11.025 & 0.000 \\
\hline sq5.1<- SQ & 0.863 & 0.861 & 0.030 & 29.011 & 0.000 \\
\hline sq6.1<- SQ & 0.800 & 0.799 & 0.039 & 20.249 & 0.000 \\
\hline sq7.1<- SQ & 0.745 & 0.747 & 0.048 & 15.650 & 0.000 \\
\hline sq8.1<- SQ & 0.842 & 0.845 & 0.030 & 28.452 & 0.000 \\
\hline sq9.2<- SQ & 0.805 & 0.804 & 0.040 & 20.154 & 0.000 \\
\hline us $1.1<-$ US & 0.833 & 0.834 & 0.053 & 15.838 & 0.000 \\
\hline us2.1<- US & 0.907 & 0.907 & 0.022 & 41.189 & 0.000 \\
\hline us $3.1<-$ US & 0.909 & 0.909 & 0.020 & 45.195 & 0.000 \\
\hline us4.1<- US & 0.930 & 0.929 & 0.022 & 43.248 & 0.000 \\
\hline us $5.1<-$ US & 0.865 & 0.866 & 0.034 & 25.532 & 0.000 \\
\hline use $1.1<-$ USE & 0.953 & 0.954 & 0.010 & 95.323 & 0.000 \\
\hline use $2.1<-$ USE & 0.951 & 0.950 & 0.014 & 65.907 & 0.000 \\
\hline
\end{tabular}




\section{Discriminant Validity}

Utilized to show that latent constructs predict the size of a particular block is better than the size of another block. Discriminant validity can be seen from the cross loading value. The indicator correlation value for the construct (latent variable) must be higher than the correlation value between the indicator and the other constructs. In table 6 , it can be seen that the indicator correlation value for the construct (latent variable) is higher than the correlation value between indicators and other constructs.

\begin{tabular}{|c|c|c|c|c|c|c|}
\hline & IQ & NB & SEQ & SQ & us & USE \\
\hline iq 1.1 & 0.832 & 0.634 & 0.656 & 0.667 & 0.652 & 0.365 \\
\hline iq 10.1 & 0.801 & 0.648 & 0.604 & 0.573 & 0.658 & 0.377 \\
\hline iq2.1 & 0.744 & 0.490 & 0.538 & 0.407 & 0.499 & 0.308 \\
\hline iq3.1 & 0.852 & 0.608 & 0.729 & 0.639 & 0.676 & 0.290 \\
\hline iq4.1 & 0.865 & 0.598 & 0.717 & 0.689 & 0.665 & 0.349 \\
\hline iq7.1 & 0.785 & 0.576 & 0.679 & 0.627 & 0.647 & 0.360 \\
\hline iq8.1 & 0.839 & 0.699 & 0.780 & 0.720 & 0.760 & 0.340 \\
\hline iq9.1 & 0.790 & 0.639 & 0.669 & 0.641 & 0.640 & 0.348 \\
\hline nb1.1 & 0.767 & 0.845 & 0.687 & 0.694 & 0.758 & 0.336 \\
\hline $\mathrm{nb} 2.1$ & 0.562 & 0.861 & 0.580 & 0.532 & 0.659 & 0.375 \\
\hline nb3.1 & 0.606 & 0.892 & 0.565 & 0.564 & 0.714 & 0.456 \\
\hline $\mathrm{nb} 4.1$ & 0.706 & 0.903 & 0.709 & 0.652 & 0.780 & 0.491 \\
\hline $\mathrm{nb} 5.1$ & 0.591 & 0.817 & 0.591 & 0.666 & 0.673 & 0.475 \\
\hline nb6.1 & 0.550 & 0.706 & 0.565 & 0.530 & 0.592 & 0.346 \\
\hline nb7.1 & 0.537 & 0.711 & 0.517 & 0.441 & 0.474 & 0.133 \\
\hline nb8.1 & 0.582 & 0.773 & 0.553 & 0.567 & 0.550 & 0.352 \\
\hline seq 1.2 & 0.675 & 0.606 & 0.771 & 0.572 & 0.694 & 0.475 \\
\hline seq 1.3 & 0.700 & 0.625 & 0.862 & 0.705 & 0.679 & 0.315 \\
\hline seq2.1 & 0.685 & 0.527 & 0.818 & 0.577 & 0.627 & 0.359 \\
\hline seq 2.2 & 0.728 & 0.621 & 0.830 & 0.661 & 0.712 & 0.358 \\
\hline seq2.3 & 0.588 & 0.616 & 0.806 & 0.572 & 0.617 & 0.312 \\
\hline sq11.1 & 0.694 & 0.563 & 0.642 & 0.767 & 0.613 & 0.344 \\
\hline sq11.2 & 0.620 & 0.558 & 0.595 & 0.754 & 0.530 & 0.180 \\
\hline sq3.1 & 0.485 & 0.495 & 0.525 & 0.759 & 0.515 & 0.266 \\
\hline sq3.2 & 0.426 & 0.426 & 0.447 & 0.720 & 0.448 & 0.178 \\
\hline sq4.1 & 0.570 & 0.550 & 0.592 & 0.730 & 0.560 & 0.143 \\
\hline sq5.1 & 0.611 & 0.563 & 0.605 & 0.863 & 0.702 & 0.349 \\
\hline sq6.1 & 0.547 & 0.490 & 0.525 & 0.800 & 0.495 & 0.294 \\
\hline sq7.1 & 0.613 & 0.613 & 0.529 & 0.745 & 0.603 & 0.318 \\
\hline sq8.1 & 0.711 & 0.680 & 0.711 & 0.842 & 0.751 & 0.486 \\
\hline sq9.2 & 0.643 & 0.595 & 0.665 & 0.805 & 0.591 & 0.339 \\
\hline us 1.1 & 0.760 & 0.617 & 0.759 & 0.631 & 0.833 & 0.435 \\
\hline us 2.1 & 0.711 & 0.736 & 0.745 & 0.731 & 0.907 & 0.477 \\
\hline us3.1 & 0.730 & 0.780 & 0.727 & 0.735 & 0.909 & 0.475 \\
\hline us 4.1 & 0.692 & 0.751 & 0.708 & 0.662 & 0.930 & 0.444 \\
\hline us5.1 & 0.683 & 0.702 & 0.702 & 0.613 & 0.865 & 0.556 \\
\hline use 1.1 & 0.397 & 0.448 & 0.432 & 0.355 & 0.522 & 0.953 \\
\hline use2.1 & 0.404 & 0.439 & 0.424 & 0.387 & 0.500 & 0.951 \\
\hline
\end{tabular}




\section{Construction Reliability}

Reliability testing in this study uses Composite Reliability because it is better at estimating the internal consistency of a contract. A composite reliability value higher than 0.6 states that the construct is reliable.

Table7. Construct Reliability and Validity

\begin{tabular}{|l|l|l|r|r} 
& Cronbach's Alpha & rho_A & Composite Reliability & Average Variance Extracted (AVE) \\
\hline IQ & 0.927 & 0.930 & 0.940 & 0.663 \\
\hline NB & 0.928 & 0.938 & 0.941 & 0.667 \\
\hline SEQ & 0.876 & 0.877 & 0.910 & 0.669 \\
\hline SQ & 0.928 & 0.939 & 0.939 & 0.608 \\
\hline US & 0.934 & 0.935 & 0.950 & 0.791 \\
\hline USE & 0.897 & 0.897 & 0.951 & 0.907
\end{tabular}

\subsection{Structural Model / Inner Model Test}

The inner model describes the relationship between latent variables based on substantive theory. Inner model testing is done to determine the relationship between constructs as hypothesized in this study.

Table 8. R-Square

\begin{tabular}{|l|r|r|} 
& R Square & R Square Adjusted \\
\hline NB & 0.655 & 0.647 \\
\hline US & 0.765 & 0.754 \\
\hline USE & 0.212 & 0.185 \\
\hline
\end{tabular}

The R-square value is $0.765 ; 0.212$; and 0.655 for endogenous variables in the structural model indicates that the model is great. From the results of data processing with SmartPLS the significance test is obtained as in the following table 
Table 9. Total Effect

\begin{tabular}{|c|c|c|c|c|c|}
\hline & Original Sample $(O)$ & Sample Mean (M) & Standard Deviation (STDEV) & T Statistics (|O/STDEV|) & P Values \\
\hline IQ $->$ NB & 0.236 & 0.242 & 0.098 & 2.416 & 0.016 \\
\hline IQ $\rightarrow$ US & 0.294 & 0.293 & 0.112 & 2.617 & 0.009 \\
\hline IQ -> USE & 0.118 & 0.128 & 0.196 & 0.603 & 0.547 \\
\hline $\mathrm{SEQ} \Rightarrow \mathrm{NB}$ & 0.326 & 0.327 & 0.074 & 4.400 & 0.000 \\
\hline SEQ $>$ US & 0.399 & 0.405 & 0.088 & 4.550 & 0.000 \\
\hline SEQ $->$ USE & 0.294 & 0.305 & 0.206 & 1.426 & 0.155 \\
\hline $\mathrm{SQ}->\mathrm{NB}$ & 0.185 & 0.181 & 0.076 & 2.431 & 0.015 \\
\hline$S Q \rightarrow$ US & 0.231 & 0.227 & 0.090 & 2.568 & 0.011 \\
\hline SQ -> USE & 0.076 & 0.069 & 0.179 & 0.423 & 0.672 \\
\hline US $\Rightarrow N B$ & 0.784 & 0.787 & 0.061 & 12.916 & 0.000 \\
\hline USE $->N B$ & 0.188 & 0.185 & 0.078 & 2.409 & 0.016 \\
\hline USE $\rightarrow$ US & 0.182 & 0.182 & 0.058 & 3.155 & 0.002 \\
\hline
\end{tabular}

Figure 3. Display of Structural Model Output

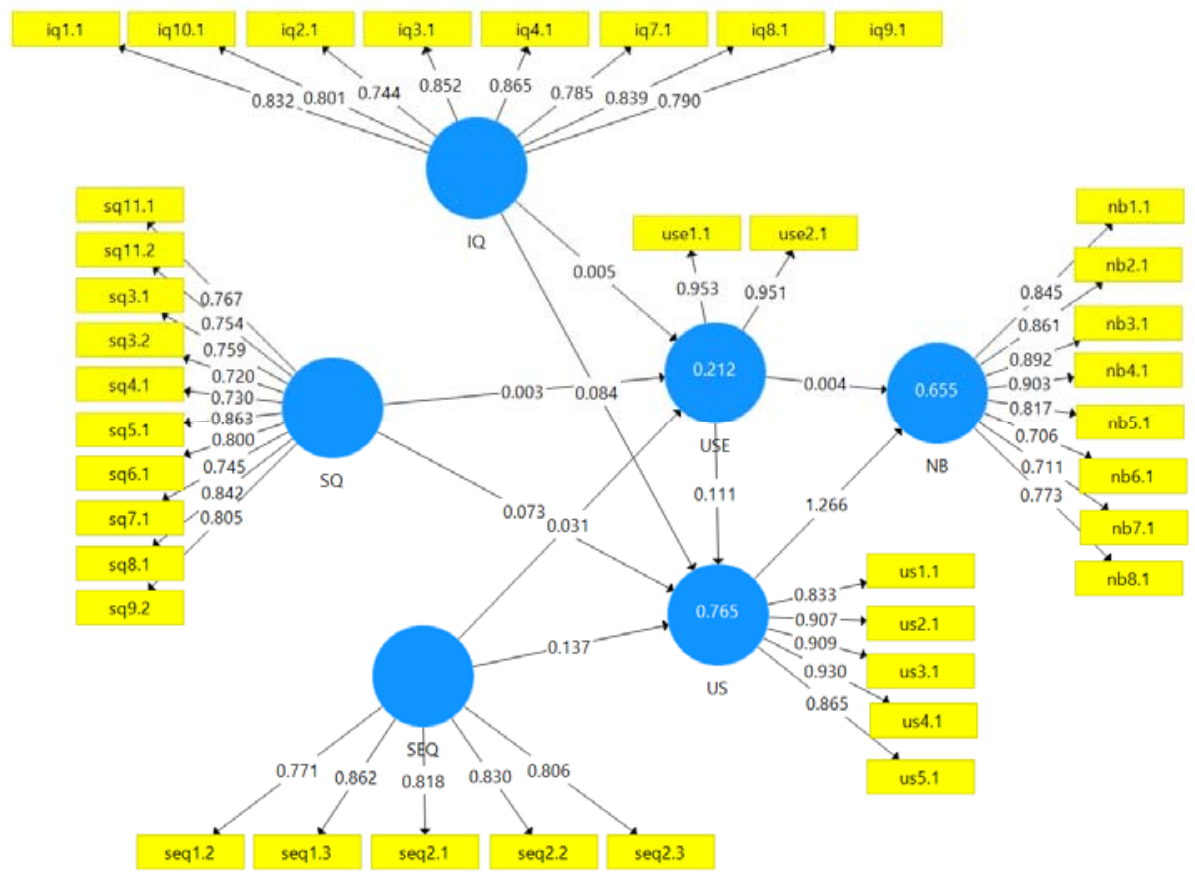

Source: Results of SmartPLS Output 3.2.8

\subsection{Empirical Model of Research}

Based on the results of the research hypothesis testing with the title "Effect of System Quality, Information Quality, Service Quality on User Usage and 
Satisfaction and Its Impact on Net Benefits (Study of Information System Users Lecturer Performance Load (BKD) of Malang State University", then empirical research models were found of relationships between variables as shown in the following figure 4 .

Figure 4. Empirical Model of Research Results

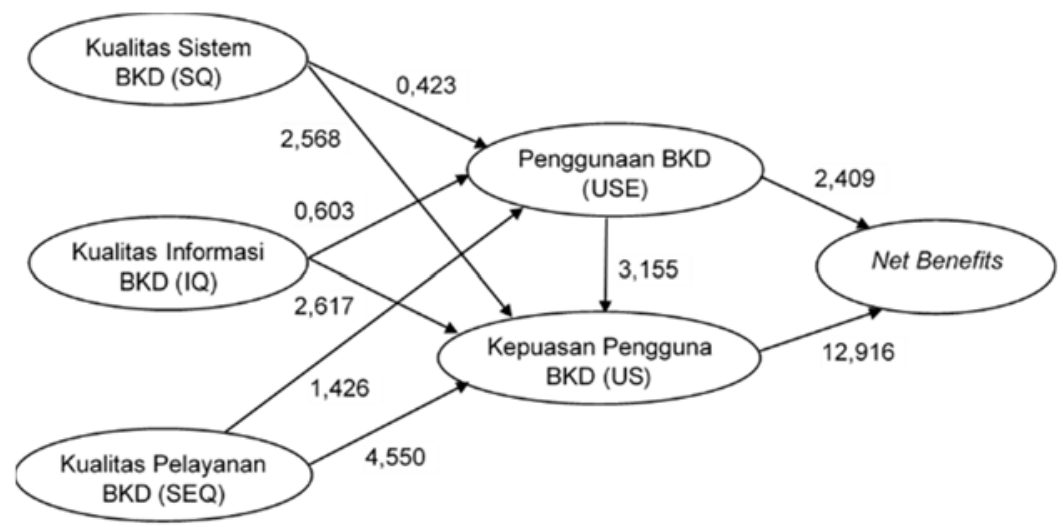

5. Conclusions

Based on testing the hypothesis, the results of the analysis, and discussing the results of the study, then conclusions can be put forward as follows:

1. There is a positive but not significant effect between the quality of the system on the use of the BKD system. Users feel comfortable and easy to access the system. However, the frequency of users accessing the BKD system is not frequent.

2. System quality has a positive and significant effect on BKD user satisfaction. Satisfaction achieved when expectations are following reality. The more system users assume that the quality of the BKD UM information system is high, the system users will be more satisfied with the information system. BKD system users are satisfied with the entire system because what is expected by the user has been fulfilled.

3. There is a positive but not significant influence between the quality of information on the use of the BKD system. Users judge that the information 
obtained from the system is, but the frequency of users accessing the BKD system is not frequent.

4. Information quality has a positive and significant effect on BKD user satisfaction. User satisfaction earns if expectations are following reality. The more system users assume that the information quality of BKD UM is high, the system users will be more satisfied with the information system. BKD system users are satisfied with the entire system because the information generated by the BKD UM information system is excellent and accurate so that what is expected by the user has been fulfilled.

5. There is a positive but significant influence between the quality of service on the use of the BKD system. Users feel safe in accessing or sending data through the system, and the system is always accessible properly, but the frequency of users accessing the BKD system is not frequent.

6. Service quality has a positive and significant effect on BKD user satisfaction. User satisfaction achieved if expectations are following reality. The more system users assume that the service quality of the UM BKD system is high, the system users will be more satisfied with the information system. BKD system users are satisfied with the entire system because what is expected by the user has been fulfilled.

7. The use of the BKD system has a positive and significant effect on BKD user satisfaction. Users of the BKD UM information system are satisfied so that it will have a positive impact on user satisfaction.

8. There is a positive and significant influence between the use of the BKD system on net benefits. The higher the use of the BKD information system, the user will get the net benefits of the BKD system such as increasing performance productivity so that the right results are obtained.

9. There is a positive and significant influence between BKD user satisfaction on net benefits. The more users of the BKD UM information system are satisfied, the positive benefits of the net benefits system, namely the BKD system can reduce costs, especially operational organizations and can provide benefits to the organization in decision making.

10. Based on the data analysis of the results of research and evaluation models in this study, the application of the BKD UM information system can be declared successful because there is a positive correlation between variables. 


\section{References}

[1]. Indonesia, P. R. (2012). Undang-undang Republik Indonesia nomor 12 tahun 2012 tentang pendidikan tinggi.

[2]. Wiyono, B. B., \& Sunarni. (2009). Evaluasi Program Pendidikan dan Pembelajaran. Malang: FIP Universitas Negeri Malang

[3]. UM. (2015). Rencana Strategis Bisnis Universitas Negeri Malang 2015 - 2019. Malang.

[4]. Birokrasi, M. P. A. N. dan R. (2015). Road map Reformasi Birokrasi 2015 - 2019. Jakarta.

[5]. AL Athmay, Al. A. A., Fantazy, K., \& Kumar, V. (2016). E-government adoption and user's satisfaction: an empirical investigation. EuroMed Journal of Business, 11(1), 57-83. https://doi.org/10.1108/EMJB-05-2014-0016

[6]. Delone, W., \& Mclean, E. (1992). Information Systems Success : The Quest for the Dependent Variable, (October 2014). https://doi.org/10.1287/isre.3.1.60

[7]. Seddon, P. B. (1997). A Respecification and Extension of the DeLone and McLean Model of IS Success. Information Systems Research. https://doi.org/10.1287/isre.8.3.240

[8]. Delone, W., \& Mclean, E. (2003). The DeLone and McLean Model of Information Systems $\begin{array}{lllll}\text { Success : } & \text { A } & \text { Ten-Year }\end{array}$ https://doi.org/10.1080/07421222.2003.11045748

[9]. Efiloğlu Kurt, Ö. (2018). Examining an e-learning system through the lens of the information systems success model: Empirical evidence from Italy. Education and Information Technologies. https://doi.org/10.1007/s10639-018-9821-4

[10]. Darmawan, D., \& Fauzi, K. N. (2013). Sistem Informasi Manajemen. Bandung: PT Remaja Rosdakarya.

[11]. Jogiyanto, \& Willy, A. (2011). Sistem Tatakelola Teknologi Informasi. Yogyakarta: Andi Offset.

[12]. Wu, J. W. (2007). Extending The Delone and McLean Information System Success Model for E-Commerce Website Success. (Thesis, Ed.). Las Vegas: University Of Nevada.

[13]. Gorla, N., Somers, T. M., \& Wong, B. (2010). Organizational impact of system quality, information quality, and service quality. Journal of Strategic Information Systems, 19(3), 207228. https://doi.org/10.1016/j.jsis.2010.05.001

[14]. Saha, P., Nath, A. K., \& Salehi-Sangari, E. (2012). Evaluation of government e-tax websites: An information quality and system quality approach. Transforming Government: People, Process and Policy, 6(3), 300-321. https://doi.org/10.1108/17506161211251281

[15]. Radityo, D., \& Zulaikha. (2007). Pengujian Model DeLone and McLean Dalam Pengembangan Sistem Informasi Manajemen ( Kajian Sebuah Kasus ). Simposium Nasional Akuntansi X, 1-25.

[16]. Supriyono. (2017). Analisis Kesuksesan Sistem Informasi Perpustakaan Di Universitas Negeri Yogyakarta (UNY) Dengan Pendekatan Model Delone Dan Mclean. Pendidikan Teknik Informatika, (1), 1-10.

[17]. Sharma, G., \& Lijuan, W. (2015). The effects of online service quality of e-commerce Websites on user satisfaction. The Electronic Library, 33(3), 468-485. https://doi.org/10.1108/EL-102013-0193

[18]. Nugroho, N., Utami, E., \& Taufiq, E. (2013). Analisis Perbandingan Kualitas Pelayanan Penerimaan Mahasiswa Baru ( PMB ) Online Menggunakan Model Kesuksesan Sistem Informasi DeLone dan McLean ( D \& M ) ( Studi Kasus : PMB UKDW dan PMB STMIK AMIKOM Yogyakarta ). Jurnal Teknologi Informasi, VIII. 


\section{HOLISTICA Vol 10, Issue 3, 2019}

[19]. Rana, N. P., Dwivedi, Y. K., Williams, M. D., \& Weerakkody, V. (2014). Investigating success of an e-government initiative: Validation of an integrated IS success model. Information Systems Frontiers, 17(1), 127-142. https://doi.org/10.1007/s10796-014-9504-7

[20]. Almaiah, M. A., \& Alismaiel, O. A. (2018). Examination of factors influencing the use of mobile learning system: An empirical study. Education and Information Technologies, 23. https://doi.org/10.1007/s10639-018-9810-7

[21]. Li, E. Y. (1997). Perceived importance of information system success factors: A meta analysis of group differences. Information \& Management, 32(1), 15-28. https://doi.org/10.1016/S0378-7206(97)00005-0

[22]. Livari, J. (2005). An empirical test of the DeLone-McLean model of information system success. ACM SIGMIS Database, 36(2), 8-27. https://doi.org/10.1145/1066149.1066152

[23]. Zheng, Y., Zhao, K., \& Stylianou, A. (2013). The impacts of information quality and system quality on users' continuance intention in information-exchange virtual communities: An empirical investigation. Decision Support Systems, 56(1), 513-524. https://doi.org/10.1016/j.dss.2012.11.008

[24]. Jogiyanto H.M. (2007). Model Kesuksesan Sistem Teknologi Informasi (I). Yogyakarta: Andi Offset.

[25]. Yamin, S., \& Kurniawan, H. (2009). Struktural Equation Modeling: Belajar Lebih Mudah Teknik Analisis Data Kuesioner dengan Lisrel - PLS. Jakarta: Salemba Infotek.

[26]. Urbach, N., \& Müller, B. (2012). The Updated DeLone and McLean Model of Information Systems Success. https://doi.org/10.1007/978-1-4419-6108-2_1

[27]. Marakas, G. M., \& O’Brien, J. A. (2017). Pengantar Sistem Informasi. Jakarta: Salemba Empat.

[28]. Davis, F. D. (1989). Perceived Usefulness, Perceived Ease of Use, and User Acceptance of Information Technology. MIS Quarterly, 13(3), 319. https://doi.org/10.2307/249008

[29]. Dirjendikti. (2010). Pedoman Beban Kerja Dosen dan Evaluasi Pelaksanaan Tridharma Perguruan Tinggi, 1. https://doi.org/10.1017/СВ09781107415324.004. 